\title{
The effect of single or combined dietary supplementation of prebiotics, organic acid and probiotics on performance and slaughter characteristics of broilers
}

\author{
M. Bozkurt", K. Küçükyılmaz, A.U. Çatlı and M. Çınar \\ Poultry Research Institute, 09600 Erbeyli-Aydın, Turkey
}

\begin{abstract}
A study was conducted to investigate the effect of dietary supplementation of an organic acid, a probiotic or a prebiotic alone or the prebiotic combined with the organic acid or the probiotic on the performance and slaughter characteristics of broiler chickens fed a maize-soya based diet. The six dietary treatments were: a basal diet (negative control) and diets containing $0.5 \mathrm{~g}$ mannan oligosaccharide $/ \mathrm{kg}$ (prebiotic), or $1.0 \mathrm{~g}$ formic acid $/ \mathrm{kg}$ (organic acid), or a probiotic at $0.5 \mathrm{~g} / \mathrm{kg}$, or $0.5 \mathrm{~g}$ prebiotic $/ \mathrm{kg}+1.0 \mathrm{~g}$ organic acid $/ \mathrm{kg}$, or $0.5 \mathrm{~g}$ prebiotic $/ \mathrm{kg}+0.5 \mathrm{~g}$ probiotic $/ \mathrm{kg}$ feed. Each treatment consisted of eight pens with 50 birds per pen $(25$ male +25 female). All dietary supplements, alone and in combination improved live weight significantly at both 21 and 42 days of age compared with the control. However, combinations of the prebiotic with either the organic acid or the probiotic had no additive benefit at 21 and 42 days of age in comparison with the prebiotic alone. The feed intake of the birds was significantly increased with prebiotic supplementation at day 21 , but not at day 42 . Organic acid significantly improved feed conversion ratio at day 21. The combination of prebiotic and probiotic significantly improved the feed conversion ratio at both 21 and 42 days in comparison with the control. At days 21 and 42 bird mortality was significantly higher in the treatments containing organic acid and organic acid with the prebiotic. In the female birds no slaughter traits were affected by dietary treatments. However, liver weight as a percentage of live weight in the male birds was significantly lowered with prebiotic and probiotic supplementation. Prebiotic supplementation with organic acid resulted in a significantly lower weight of the small intestines compared with the control. In general, the different feed additive regimens that include the prebiotic, probiotic, organic acid, prebiotic with organic acid and prebiotic with probiotic improved the growth rate of the birds significantly compared to the control treatment. The significant improvement in feed conversion ratio when the prebiotic and probiotic were supplemented together suggests a synergism between them.
\end{abstract}

Keywords: Prebiotic, organic acid, probiotic, broiler, performance, slaughter characteristics

${ }^{\#}$ Corresponding author. E-mail: mehmetbozkurt9@hotmail.com

\section{Introduction}

Feed additive antibiotics have been used as growth promoters for more then 50 years in the feed industry all over the world. The mode of action of antibiotics is the suppressing of the detrimental effect of pathogenic bacteria in the gut. Since the proposed total ban on sub-therapeutic feed antibiotics, products such as prebiotics, organic acids and probiotics are receiving considerable attention in animal nutrition because of their non-residual and non-resistant properties (Mellor, 2000; Gill, 2001; Hertrampf, 2001; Kocher, 2005; Plail, 2006). The beneficial effects on protein and energy digestibility and also on immune stimulation of these additives have been demonstrated in detail in previous studies. Probiotics (Vanbella et al., 1990; Jin et al., 1998) and prebiotics (Shane, 2001; Ferket, 2004) act as growth promoters feed savers, nutritional bioregulators, immune stimulators and help in improving performance and health.

Feed organic acids suppress the growth of certain species of bacteria, particularly acid-intolerant species such as E. coli, Salmonella spp. and Campylobacter ssp. (Ricke, 2003; Dibner, 2004; Lückstadt, 2005). Their principal role is to lower and stabilize the $\mathrm{pH}$ in the stomach and intestines so that the gut environment is too acidic for normal bacterial growth. Additionally, they improve protein digestion in young animals by stimulating pancreatic enzyme secretion. Thus, dietary organic acids suppress the growth of pathogenic bacteria, encourage the growth of beneficial microflora and ensure that the digestive enzymes 
function at maximal capacity (Broek, 2000; Mellor, 2000; Dibner \& Winter, 2002; Ricke, 2003; Best, 2004; Dibner, 2004).

Prebiotics are defined as non-digestive feed ingredients that beneficially affect the host by selectively stimulating the growth and/or activity of one or a limited number of bacterial species already resident in the digestive tract. The prebiotic, mannan oligosaccharide (MOS), is a carbohydrate, derived from yeast cell walls, and can block pathogenic bacterial proliferation and stimulate the non-specific immune system; thus tending to improve the health and growth performance of birds (Hertampf, 2001; Iji et al., 2001; Shane, 2001; Ferket, 2004; Kocher, 2005). Probiotics are pure cultures of one or more live microorganisms given orally. They proliferate in the gastrointestinal tract (GI) of the host and ensure that the bird maintains a beneficial microbial population in the GI tract by limiting the damage caused by pathogenic bacteria, reinforcing intestinal mucosal integrity and creating a positive balance of digestive microflora. Improved epithelial cell integrity, increased immune response, well balanced gut microflora, better utilisation and digestion of diet are also additive beneficial effects of dietary probiotics (Vanbella et al., 1990; Jin et al., 2000; Wenk, 2000; Panda et al., 2001; Linge, 2005).

The beneficial effects of the dietary supplementation of organic acids (Skinner et al., 1991; Denli et al., 2003; Alçiçek et al., 2004; Şenköylü et al., 2005), prebiotics (Kumprecht et al., 1997; Sims \& Sefton, 1999; Hooge et al., 2003, Hooge, 2004; Bozkurt et al., 2005) and probiotics (Yeo \& Kim, 1997; Cavozzoni et al., 1998; Jin et al., 1998; Abdulrahim et al., 1999; Alçiçek et al., 2004, Molnár et al., 2005) on broiler performance are well documented. However, there is lack of information on the combined supplementing of prebiotics and organic acids, and prebiotics and probiotics as performance enhancer feed additives. A prebiotic preparation (MOS) has been shown to interfere with the use of antibiotics in diets of broilers (Waldroup et al., 2003a), whereas no benefit has been found relating response of broiler live performance to dietary added MOS in the presence of a probiotic (Hofacre et al., 2003). On the other hand Hooge et al. (2003) reported that MOS alone supported live performance equivalent to antibiotic growth promoters but showed an additive effect when combined with antibiotics. Therefore, the objective of the present study was to examine the performance and some slaughter characteristics of broiler chickens fed an experimental diet containing a prebiotic, an organic acid or a probiotic, and also the prebiotic in combination with either the organic acid or the probiotic. Since limited evidence is available on the potential of combining prebiotics with favourable antibiotic alternatives, the objective of this trial was not only to demonstrate the effectiveness of individual supplements, but also to find the most effective synergistic combination of these products.

\section{Materials and Methods}

Two thousand and four hundred sexed day-old broiler chicks (Ross 308) were divided into six treatment groups of 400 birds each and randomly assigned to six treatment diets. The six dietary treatments were: 1. Basal diet (negative control); 2. PRE (prebiotic); basal diet with the prebiotic, mannan oligosaccharide, (Nutri-Mos ${ }^{\circledR}$, Lesaffre) at $0.5 \mathrm{~g} / \mathrm{kg}$ diet; 3. ORA (organic acid); basal diet with the organic acid, formic acid, (BASF) at $1.0 \mathrm{~g} / \mathrm{kg}$ diet; 4. PRO (probiotic); basal diet with the probiotic consisting of a combined preparation of live microorganisms including Lactobacillus acidophilus, Lactobacillus casei, Enterococcus faecium and Bifidobacterim bifidum (Primalac ${ }^{\circledR}$ Star*labs) at $0.5 \mathrm{~g} / \mathrm{kg}$ diet; 5. PRE+ORA (prebiotic+organic acid); basal diet with prebiotic +organic acid $(0.5 \mathrm{~g} / \mathrm{kg}$ diet $+1.0 \mathrm{~g} / \mathrm{kg} \mathrm{diet}) ; 6$. PRE+PRO (prebiotic+probiotic); basal diet with prebiotic+probiotic $(0.5 \mathrm{~g} / \mathrm{kg}$ diet $+0.5 \mathrm{~g} / \mathrm{kg}$ diet $)$. The experimental feed additives were added to basal diet at the expense of sawdust. The ingredients and chemical composition of the diets are presented in Table 1. The diets were isoenergetic and isonitrogenous and formulated to meet the minimum nutrient requirements of broilers (NRC, 1994). The diets in mash form and water were provided ad libitum.

The chicks were placed in an open-sided naturally ventilated broiler house and standard management practices were applied. Each treatment group was sub-divided into eight replicates of 50 birds (25 male and 25 female) per replicate and kept in 48 pens $(1.4 \times 3.0 \mathrm{~m})$ on wood shavings as litter material. A photoperiod of $23 \mathrm{~h} / \mathrm{d}$ was maintained. The experiment lasted for 42 days, during late September and October of 2004. Each pen was equipped with two hanging feeders, one bell drinker and two infrared lamps. Bird density was 12 chicks per square metre. The ambient temperature in an experimental house was maintained at $32{ }^{\circ} \mathrm{C}$ during the first week and gradually decreased by $3{ }^{\circ} \mathrm{C}$ in the second and third week and exposed to natural 
environmental conditions thereafter. Chicks were vaccinated against Infectious Bursal Disease, New Castle Diseases HB1 and La sota at days 14, 21 and 28, respectively, via the drinking water. During the $42 \mathrm{~d}$ experimental period, the growth performance of broiler chickens was evaluated by recording body weight, feed intake, feed conversion ratio and mortality. Birds were weighted individually at 1, 21 and $42 \mathrm{~d}$ of age. Feed intake per pen was recorded at 21 and $42 \mathrm{~d}$ of age. Feed conversion ratio (FCR) was adjusted for weight of chicks at first day and FCR was calculated at the end of the 21-day and 42-day experimental periods. The FCR was calculated as feed consumed per unit of body weight gain and adjusted for mortality. Mortality was recorded daily. At the end of the experiment (at $42 \mathrm{~d}$ ), 12 male and 12 female birds of similar body weight to the group average of each sex were selected from each treatment group (two males and two females per replicate), weighted and killed by severing of the brancial vein. After evisceration, hot carcasses were weighted immediately to determine the hot carcass yield. The weights of the pancreas, liver without gall bladder, small intestines without content and the abdominal fat pad were recorded individually. The weights of these selected internal organs were expressed as a percentage of preslaughter live weight of the broilers.

The standard techniques of the proximate analysis were used to determine the nutrient concentrations in the diets (Naumann \& Bassler, 1993). The experimental diets were also analyzed for starch, sugar, total calcium and phosphorus according to methods described by the Association of German Agricultural Analysis and Research Institutes (VDLUFA) (Naumann \& Bassler, 1993). Metabolisable energy content of the diets was calculated based on chemical composition (Anonymous, 1991). The data obtained from this study were analyzed statistically using the General Linear Models procedure of SAS (1991). Significant differences between treatment means were separated using the Duncan's multiple range test with $5 \%$ probability.

Table 1 The Ingredients and chemical composition of the basal starter and grower diets (as fed)

\begin{tabular}{|c|c|c|c|c|c|}
\hline \multirow{2}{*}{ Ingredients $(\mathrm{g} / \mathrm{kg})$} & \multirow{2}{*}{ Starter diet } & \multirow{2}{*}{ Grower diet } & \multicolumn{3}{|c|}{ Chemical composition of basal diet (g/kg) } \\
\hline & & & & Starter diet & Grower diet \\
\hline Maize & 450.26 & 496.25 & Dry matter & 887.9 & 889.2 \\
\hline Wheat & 100.00 & 100.00 & Crude protein & 221.3 & 203.7 \\
\hline Soyabean meal $(0.48)$ & 241.74 & 202.14 & Crude fat & 70.3 & 83.2 \\
\hline Full-fat soyabean & 150.00 & 138.53 & Crude fibre & 34.5 & 32.9 \\
\hline Soyabean oil & 19.53 & 29.67 & Crude ash & 59.6 & 55.2 \\
\hline Dicalcium phosphate & 21.09 & 18.44 & Starch & 353.2 & 369.6 \\
\hline Ground limestone & 4.15 & 3.28 & Sugar & 31.2 & 32.1 \\
\hline Salt & 3.80 & 3.80 & Calcium & 9.3 & 8.6 \\
\hline L-Lysine HCL & 0.48 & 0.00 & Phosphorus (total) & 6.9 & 6.3 \\
\hline DL-methionine & 2.45 & 1.89 & \multicolumn{3}{|c|}{ Calculated composition $(\mathrm{g} / \mathrm{kg})$} \\
\hline Vitamin premix $^{1}$ & 2.50 & 2.50 & Available phosphorus & 4.7 & 4.2 \\
\hline Mineral premix ${ }^{2}$ & 1.00 & 1.00 & Lysine & 12.5 & 10.3 \\
\hline Anticoccidial & 0.50 & 0.50 & Methionine & 5.7 & 4.9 \\
\hline Antioxidant & 1.00 & 1.00 & Methionine+cysteine & 9.2 & 8.0 \\
\hline Sawdust & 1.50 & 1.50 & Linoleic acid & 35.1 & 39.8 \\
\hline Total & 1000 & 1000 & $\begin{array}{l}\text { Metabolisable energy } \\
(\mathrm{MJ} / \mathrm{kg})\end{array}$ & 12.93 & 13.44 \\
\hline
\end{tabular}

${ }^{1}$ Supplied per kg of diet: $12000 \mathrm{IU}$ vitamin $\mathrm{A} ; 1500 \mathrm{IU}$ vitamin $\mathrm{D}_{3} ; 30 \mathrm{mg}$ vitamin $\mathrm{E} ; 5 \mathrm{mg}$ vitamin $\mathrm{K}_{3} ; 3 \mathrm{mg}$ vitamin $\mathrm{B}_{1} ; 6 \mathrm{mg}$ vitamin $\mathrm{B}_{2} ; 5 \mathrm{mg}$ vitamin $\mathrm{B}_{6} ; 0.03 \mathrm{mg}$ vitamin $\mathrm{B}_{12} ; 40 \mathrm{mg}$ nicotine amid; $10 \mathrm{mg}$ calcium-D-pantothenate; $0.75 \mathrm{mg}$ folic acid; $0.075 \mathrm{mg}$ D-biotin; $375 \mathrm{mg}$ choline chloride.

${ }^{2}$ Supplied per kg of diet: $80 \mathrm{mg} \mathrm{Mn} ; 40 \mathrm{mg} \mathrm{Fe} ; 60 \mathrm{mg} \mathrm{Zn;} 5 \mathrm{mg} \mathrm{Cu} ; 0.5 \mathrm{mg} \mathrm{I} ; 0.2 \mathrm{mg} \mathrm{Co}$; $0.15 \mathrm{mg} \mathrm{Se.}$

\section{Results and Discussion}

The supplemental effects of PRE, ORA, PRO, and PRE in combination with either ORA or PRO on live performance of broiler chickens are shown in Table 2. All dietary supplements, either alone or in 
combination, improved $(21 \mathrm{~d}, \mathrm{P}<0.01 ; 42 \mathrm{~d}, \mathrm{P}<0.05)$ body weight to a similar extent compared with the control. However, combining the prebiotic with either organic acid or the probiotic had no additive benefit at both 21 and $42 \mathrm{~d}$ in comparison with the prebiotic treatment alone. These results clearly show that the prebiotic, organic acid and probiotic stimulated the growth of broilers during the entire experimental period. Compared to the control, improved growth rates of $4.2-5.1 \%$ were measured during starter period and $1.9-2.5 \%$ for the entire experimental period. These results confirm the growth promoting effect of supplemental organic acids as reported by Skinner et al. (1991), Alçiçek et al. (2004), Şenköylü et al. (2005); that of prebiotics reported by Kumprecht et al. (1997), Sims \& Sefton (1999); Sefton et al. (2002), Bozkurt et al.(2005) and that of probiotics observed by Cavazzoni et al. (1998), Jin et al. (1998), Molnár et al. (2005).

The beneficial effect of organic acids in pig diets has been well documented, but similar responses were inconsistent in studies on broilers. While Skinner et al. (1991) reported that fumaric acid supplementation into diet at the level of $0.125 \%$ increased final weight of broiler chickens $(\mathrm{P}<0.05)$, no beneficial effect of dietary organic acids on body weight was reported by other investigators (Izat et al., 1990a; b; Hadorn et al., 2000). Furthermore, contrary to our findings, Patten \& Waldroup (1988) found that the addition of $1.5 \%$ calcium formate in broiler diets reduced weight gain. However, organic acids, fed either individually or combined, offer a chemical alternative for growth promoting antibiotics (AGP) as used in poultry diets. This was accepted as a participial AGP alternative, with propionic acid, formic acid and lactic acid as the most effective and universally accepted products (Broek, 2000; Ricke, 2003; Dibner, 2004; Mabbett, 2005). Strong bactericidal and bacteriostatic effects have been demonstrated for formic acid, the shortest chain organic acid. In fact, apart from their antimicrobial properties, organic acids make a significant contribution to feed hygiene, since they suppress the growth of mould and thus restrict the potentially harmful effects of mycotoxins (McCartney, 2001; Roy et al., 2002, Lückstädt et al., 2005).

Table 2 Body weight, feed intake, feed conversion ratio and mortality of broilers receiving diet supplemented with either organic acid, probiotic, prebiotic with or without organic acid and probiotic

\begin{tabular}{lcccccccc}
\hline \multirow{2}{*}{ Treatment } & \multicolumn{4}{c}{$0-21 \mathrm{~d}$} & \multicolumn{4}{c}{$0-42 \mathrm{~d}$} \\
& \multicolumn{1}{c}{$\begin{array}{c}\text { Body } \\
\text { weight (g) }\end{array}$} & $\begin{array}{c}\text { Feed } \\
\text { intake (g) }\end{array}$ & $\begin{array}{c}\text { Feed } \\
\text { conversion }\end{array}$ & $\begin{array}{c}\text { Mortality } \\
(\%)\end{array}$ & $\begin{array}{c}\text { Body } \\
\text { weight (g) }\end{array}$ & $\begin{array}{c}\text { Feed } \\
\text { intake (g) }\end{array}$ & $\begin{array}{c}\text { Feed } \\
\text { conversion }\end{array}$ & $\begin{array}{c}\text { Mortality } \\
(\%)\end{array}$ \\
\hline Control & $721^{\mathrm{b}}$ & $1050^{\mathrm{b}}$ & $1.544^{\mathrm{a}}$ & $0.25^{\mathrm{b}}$ & $2207^{\mathrm{b}}$ & 3943 & $1.818^{\mathrm{a}}$ & $0.75^{\mathrm{b}}$ \\
Prebiotic & $764^{\mathrm{a}}$ & $1095^{\mathrm{a}}$ & $1.512^{\mathrm{ab}}$ & $0.50^{\mathrm{ab}}$ & $2256^{\mathrm{a}}$ & 4001 & $1.804^{\mathrm{ab}}$ & $1.25^{\mathrm{ab}}$ \\
Organic acid & $758^{\mathrm{a}}$ & $1060^{\mathrm{b}}$ & $1.478^{\mathrm{b}}$ & $0.75^{\mathrm{a}}$ & $2251^{\mathrm{a}}$ & 3928 & $1.775^{\mathrm{ab}}$ & $2.75^{\mathrm{a}}$ \\
Probiotic & $751^{\mathrm{a}}$ & $1080^{\mathrm{ab}}$ & $1.520^{\mathrm{ab}}$ & $0.50^{\mathrm{ab}}$ & $2258^{\mathrm{a}}$ & 3940 & $1.791^{\mathrm{ab}}$ & $0.75^{\mathrm{b}}$ \\
Prebiotic+org. acid & $754^{\mathrm{a}}$ & $1078^{\mathrm{ab}}$ & $1.513^{\mathrm{ab}}$ & $0.00^{\mathrm{b}}$ & $2248^{\mathrm{a}}$ & 3958 & $1.774^{\mathrm{ab}}$ & $2.75^{\mathrm{a}}$ \\
Prebiotic+probiotic & $755^{\mathrm{a}}$ & $1061^{\mathrm{b}}$ & $1.484^{\mathrm{b}}$ & $0.25^{\mathrm{b}}$ & $2263^{\mathrm{a}}$ & 3899 & $1.755^{\mathrm{b}}$ & $1.75^{\text {ab }}$ \\
s.e.m. & 4.42 & 9.98 & 0.016 & 0.38 & 13.75 & 36.28 & 0.017 & 0.56 \\
P value & 0.0001 & 0.0301 & 0.0476 & 0.0325 & 0.0462 & 0.4982 & 0.0494 & 0.0325
\end{tabular}

$\overline{\mathrm{a}-\mathrm{b}}$ Means within column with different superscript differ at $\mathrm{P}<0.05$.

Supplementation of the prebiotic to the diet, either alone or combined with the organic acid or the probiotic, significantly increased body weight compared to the control treatment, though differences between the three prebiotic dietary regimens were not significant. In broilers limited research has been reported on the effect of prebiotics fed in combination with other feed additive. In a recent study, Hofacre et al. (2003) reported that prebiotic (mannan oligosaccharide) supplementation to a diet with or without a probiotic (a lactic acid bacterial preparation) did not improve weight gain, feed conversion ratio or liveability of 
broilers reared for $28 \mathrm{~d}$. Similarly, Waldroup et al. (2003b) found no significant added effect on body weight and feed conversion ratio of broilers when given a prebiotic (mannan oligosaccharide) plus an antibiotic growth promoter (copper sulphate). However, the various studies demonstrated that diets containing prebiotics achieved improved performance in poultry similar to AGP or other performance enhancer feed additives (Savage et al., 1997; Sims \& Sefton, 1999; Sefton et al., 2002; Ceylan et al., 2003; Hooge et al., 2003; Bozkurt et al., 2005).

There were differences $(\mathrm{P}<0.05)$ in feed intake between the different treatments from 0 to $21 \mathrm{~d}$ of age, but not from 0 to $42 \mathrm{~d}$ of age $(\mathrm{P}>0.05)$. Dietary PRE, PRO and PRE + ORA supplementation to the diet increased feed intake during the first $21 \mathrm{~d}$ of the experiment, but this was not maintained for the rest of the study. At $21 \mathrm{~d}$, feed intake of the birds was increased with prebiotic supplementation in comparison with the control $(\mathrm{P}<0.05)$, but not at $42 \mathrm{~d}$. Consequently, the voluntary feed intake of the birds given different feed additives were similar $(\mathrm{P}>0.05)$ at $42 \mathrm{~d}$ of age. Our results are supported by the findings of Izat et al. (1990a; b); Yeo \& Kim (1997) and Sims \& Sefton (1999) who determined that dietary additions of prebiotic, organic acid and probiotic preparations respectively, did not affect feed intake of broiler chickens.

Improvements in bodyweight gain were reflected to some extent in the feed conversion ratio since the overall experimental treatments improved the feed-to-gain ratio when compared with the control treatment in both starter and the entire experimental periods. During the first 21 days significantly $(\mathrm{P}<0.05)$ improved (ca. 4.54\%) feed conversion ratios (1.48 and 1.47, respectively) were found in both the ORA and PRE+PRO groups compared with the control treatment (1.54). The dietary combination of PRE with PRO improved $(\mathrm{P}<0.05)$ feed conversion ratios at both 21 and 42 days while ORA supplementation alone improved the feed conversion ratio only for the first 21 days of the trial. These results indicate that broilers fed the PRE plus PRO were more efficient at converting feed to body mass during the rearing period. To stimulate the growth of beneficial bacteria in the gut using a prebiotic and probiotic combination was slightly more effective than the other additive programmes in this study. In general, improvements in feed efficiency were attributed to an encouraged growth of the beneficial micro flora in the GIT induced by dietary supplementation of PRE, ORA and PRO. In addition to an antimicrobial activity, a significantly increased intestinal amylase enzyme activity was determined in a recent study when adding L. acidophulus and a mixture of Lactobacilli to the diets (Jin et al., 2000). Furthermore, (Yeo \& Kim, 1997) reported that the improvement in feed efficiency of birds receiving probiotic supplemented diets could be due to decreased urease activity in the GI tract of the broiler chicks.

Even though the mode of action of those feed additives is quite different, particularly their antimicrobial activity, the similar physiologic pattern was probably exerted by modifying intestinal $\mathrm{pH}$, altering the composition and balance of intestinal flora, enhancing nutrient digestibility and improving feed conversion ratio and growth rate. Indeed, the mode of their action differs from one another, but in general they are all considered as bacteriostatic agents. The report of Abdulrahim et al. (1999) can support such a mode of action by demonstrating that dietary supplementation of an antibiotic and probiotic in combination led to superior growth performance on broiler chickens when compared with individual use of these additives. Therefore, the essential beneficial effect of feed additives used in this study might be attributable to their antibacterial properties. In agreement with the results of this study, a series of scientific reports demonstrated that addition of prebiotics (Sims \& Sefton, 1999; Shafey et al., 2001; Sefton et al., 2002; Hooge et al., 2003; Hooge, 2004; Bozkurt et al., 2005; Denev et al., 2005), organic acids (Dibner \& Winter, 2002; Alçiçek et al., 2004; Zhang et al., 2005) and probiotics (Yeo \& Kim, 1997; Abdulrahim et al., 1999; Jin et al., 1998; 2000; Molnár et al., 2005) to the diet resulted in either a numerical or significant improvement in the growth performance of birds, including body weight gain and feed efficiency.

Bird mortality differed $(\mathrm{P}<0.05)$ between the treatments at both $21 \mathrm{~d}$ and $42 \mathrm{~d}$ of age. At both 21 and 42 days of age it was higher $(\mathrm{P}<0.05)$ in the organic acid supplementation treatment as well as at 42 days in the prebiotic plus organic acid combination. It is interesting to note that any of the performance enhancer feed additives had no beneficial effect on the liveability of broiler chickens in comparison with the control. However, most of the mechanisms of action of these additives are still only hypotheses and need to be more clearly demonstrated in terms of general health status of chickens. Although overall positive effects were observed with these additives, in the form of better performance in weight gain and feed conversion efficiency, similar responses in liveability of birds were not observed in this study. This agrees with results obtained by Izat et al. (1990b), Skinner et al. (1991), Cavazzoni et al. (1998) and Jin et al. (1998). On the 
other hand, the inhibiting mechanism on pathogenic bacteria by dietary mannan oligosaccharides through the blocking of bacterial adhesion to gut lining, has been widely reported (Oyofo et al., 1989; Spring, 1999; Iji et al., 2001; Shane, 2001; Ferket, 2004). However, contrasting reports are available on the mortality of birds with respect to dietary mannan oligosaccharide supplementation. While no beneficial effect of mannan oligosaccharide was found on liveability of broilers in several studies (Waldroup et al., 2003 a; b; Ceylan et al., 2003, Hooge et al., 2003; Bozkurt et al., 2005), Hooge (2004), using a meta-analysis of 44 comparisons, pointed out that mannan oligosaccharide supplementation to diets lowered broiler mortality by $4 \%$ compared with unsupplemented controls (4.83\%). Similar to the results of our present study, Hofacre et al. (2003) provided evidence that two dietary prebiotic preparations (mannan oligosaccharide and fructo oligosaccharide), organic acid (propionic acid) and probiotic (lactic acid bacterial preparation) were not successful at lowering mortality of birds compared to the control treatment.

Table 3 Carcass weight yield and relative weights of some internal organs given diet supplemented with either organic acid, probiotic, prebiotic with or without organic acid and probiotic

\begin{tabular}{lccccccc}
\hline Treatment & $\begin{array}{c}\text { Slaughter } \\
\text { weight }(\mathrm{g})\end{array}$ & $\begin{array}{c}\text { Carcass } \\
\text { weight }(\mathrm{g})\end{array}$ & $\begin{array}{c}\text { Carcass } \\
\text { yield }(\%)\end{array}$ & $\begin{array}{c}\text { Liver } \\
(\%)\end{array}$ & $\begin{array}{c}\text { Small intes. } \\
(\%)\end{array}$ & $\begin{array}{c}\text { Pancreas } \\
(\%)\end{array}$ & $\begin{array}{c}\text { Abdominal } \\
\text { fat (\%) }\end{array}$ \\
\hline & \multicolumn{7}{c}{ Male } \\
Control & 2407 & 1757 & 72.98 & $1.96^{\mathrm{a}}$ & $2.88^{\mathrm{a}}$ & 0.24 & 1.19 \\
Prebiotic & 2409 & 1779 & 73.83 & $1.76^{\mathrm{b}}$ & $2.77^{\mathrm{a}}$ & 0.25 & 1.40 \\
Organic acid & 2403 & 1762 & 73.31 & $1.86^{\mathrm{ab}}$ & $2.86^{\mathrm{a}}$ & 0.27 & 1.31 \\
Probiotic & 2406 & 1752 & 72.82 & $1.74^{\mathrm{b}}$ & $2.63^{\mathrm{ab}}$ & 0.25 & 1.37 \\
Prebiotic + organic acid & 2427 & 1797 & 74.03 & $1.82^{\mathrm{ab}}$ & $2.48^{\mathrm{b}}$ & 0.24 & 1.38 \\
Prebiotic + probiotic & 2426 & 1796 & 74.02 & $1.80^{\mathrm{ab}}$ & $2.83^{\mathrm{a}}$ & 0.26 & 1.28 \\
s.e.m & 17.35 & 19.83 & 0.47 & 0.05 & 0.08 & 0.01 & 0.10 \\
P value & 0.862 & 0.429 & 0.301 & 0.038 & 0.014 & 0.655 & 0.72 \\
\hline & & & Female & & & & \\
\hline Control & 2099 & 1565 & 74.57 & 2.11 & 2.58 & 0.28 & 1.79 \\
Prebiotic & 2104 & 1582 & 75.16 & 2.23 & 2.72 & 0.27 & 1.69 \\
Organic acid & 2105 & 1582 & 75.15 & 2.04 & 2.77 & 0.31 & 1.70 \\
Probiotic & 2092 & 1560 & 74.61 & 2.18 & 2.75 & 0.27 & 1.66 \\
Prebiotic + organic acid & 2101 & 1589 & 75.64 & 2.17 & 2.91 & 0.27 & 1.86 \\
Prebiotic + probiotic & 2126 & 1599 & 75.24 & 2.06 & 2.80 & 0.28 & 1.84 \\
s.e.m. & 12.69 & 11.60 & 0.39 & 0.07 & 0.11 & 0.01 & 0.12 \\
P value & 0.538 & 0.180 & 0.382 & 0.454 & 0.479 & 0.113 & 0.78 \\
& & & & & & &
\end{tabular}

$\overline{\mathrm{a}-\mathrm{b}}$ Means within column with different superscript differ at $\mathrm{P}<0.05$.

The effects of the different dietary supplements on relative weight of some internal organs and carcass yield are summarized in Table 3. These results suggest that the effect of feed additive supplementation on the slaughter traits was related to sex. Carcass traits of female birds were not affected by dietary treatments $(\mathrm{P}>0.05)$, while the relative liver and small intestine weights of male birds were affected $(\mathrm{P}<0.05)$. Feeding prebiotic and probiotic supplemented diets decreased $(\mathrm{P}<0.05)$ relative liver and small intestines weights compared with the control. Well established evidence by Hill et al. (1957), Visek (1978), Henry et al. (1986) and Engberg et al. (2000) indicated that dietary inclusion of feed grade antibiotics, given as growth promoters, reduced intestine weight by thinning the intestinal wall evoked particularly by antimicrobial activity in gut lumen. However, a series of reports suggested similar antimicrobial mode of action for prebiotics (Iji et al., 2001; Shane, 2001; Ferket, 2004), organic acids (Broek, 2000; Dibner, 2004) and probiotics (Vanbella et al., 1990; Yeo \& Kim, 1997; Wenk, 2000). This is in agreement with the findings of Alçiçek et al. (2004) who reported that the dietary addition of probiotics lowered the small intestine weight. 
However, definitive data are lacking with respect to effects of dietary organic acids, probiotics and mannan oligosaccharide on the intestinal tissue of poultry in comparison to the well-documented effects of antibiotics. The effects of feed additives used in this study were associated with growth stimulation, enhanced nutrient digestion and absorption, though this enhancement was not converted to carcass yield. Similar observations were reported by Izat et al. (1990b), Skinner et al. (1991) and Zhang et al. (2005) for organic acids, by Panda et al. (2001) and Alçiçek et al. (2004) for probiotics and by Bozkurt et al. (2005), Waldroup et al. (2003) for prebiotics.

Likewise, Jin et al. (1998) and Bozkurt et al. (2005) found that dietary prebiotic and probiotic supplementation, respectively, did not stimulate the liver weights of broilers. Dietary treatments had no significant effect on abdominal fat pad accumulation in the present study. Similar results were observed by researchers who studied supplementation of prebiotics (Waldroup et al., 2003a; b; Bozkurt et al, 2005), organic acids (Izat et al., 1990b; Skinner et al., 1991) and probiotics (Denli et al., 2003; Alçiçek et al., 2004) to broiler diets. Consequently, the slaughter characteristics of both of male and female broilers were not negatively affected by the different feed additive regimens.

\section{Conclusions}

Supplementation of broiler diets with a prebiotic, an organic acid and a probiotic significantly increased the body weight gain with slightly improved feed conversion ratios, compared with the unsupplemented control. Combining the prebiotic with either the organic acid or the probiotic did not produce an additive benefit in growth performance of broilers compared with these supplements alone. However, combining strategies of prebiotic with probiotic proved more effective than that of individual use of these additives in terms of feed conversion ratio. In this case, it was shown that a prebiotic preparation is an ideal match with a probiotic preparation to optimise digestion, thus to convert feed to body mass more effectively. Therefore, improvement in feed efficiency derived from use of the prebiotic with probiotic combination, sometimes referred to as 'symbiotic', warrants further investigations.

\section{References}

Abdulrahim, S.M., Haddadin, M.S.Y., Odetallah, N.H.M. \& Robinson, R.K., 1999. Effect of Lactobacillus acidophilus and zinc bacitracin as dietary additives for broiler chickens. Br. Poult. Sci. 40, 91-94.

Alçiçek, A., Bozkurt, M. \& Çabuk, M., 2004. The effects of a mixture of herbal essential oil, an organic acid or a probiotic on broiler performance. S. Afr. J. Anim. Sci. 34, 217-222.

Anonymous, 1991. Animal feeds - Determination of metabolizable energy (chemical method). Turkish Standards Institute (TSE), Publ. No. 960, 1-3.

Best, P., 2004. Acidifiers receive a show up date. Feed Int. 25 (2), 6-8.

Bozkurt, M., Küçükyılmaz, K., Çatlı, A.U. \& Çınar, M., 2005. Growth performance and carcass yield of broiler chickens given antibiotic, mannan oligosaccharide and dextran oligosaccharide supplemented diets. Nutritional Biotechnology in the Feed and Food Industries. Proc. $21^{\text {st }}$ Annual Symp. May 22-25, 2005 Lexington, Kentucky, USA. (Suppl. 1). pp. 69.

Broek, Van den G.Ir., 2000. Organic acid: Natural link between drug and growth promoter. Feed Mix (Special), November, 9-11.

Cavazzoni, V., Adami, A. \& Castrovilli, C., 1998. Performance of broiler chickens supplemented with Bacillus coagulans as probiotics. Br. Poult. Sci. 39, 526-529.

Ceylan, N., Çiftçi, İ. \& İlhan, Z., 2003.The effects of some alternative feed additives for antibiotic growth promoters on the performance and gut microflora of broiler chicks. Turkish J. Vet. Anim. Sci. 27 (3), 727-733.

Denev, S.A., Divev, I., Nikiforov, I. \& Koinarski, V., 2005. Effects of mannanoligosaccharides on composition of cecal microflora and performance of broiler chickens. Proc. $15^{\text {th }}$ European Symposium on Poultry Nutrition. September 25-29, 2005 Balatonfüred, Hungary. pp. 351-353.

Denli, M., Okan, F. \& Çelik, K., 2003. Effect of dietary probiotic, organic acid and antibiotic supplementation to diets on broiler growth performance and carcass yield. Pakistan J. Nutr. 2 (2), 96-98.

Dibner, J., 2004. Organic acids: Can they replace antibiotic growth promoters? Feed Int. 25 (12), 14-16. 
Dibner, J.J. \& Winter, B., 2002. Use of organic acids as a model study the impact of gut microflora on nutrition and metabolism. J. Appl. Poult. Res. 10, 453-463.

Engberg, R.M., Hedemann, M.S., Leser, T.D. \& Jensen, B.B., 2000. Effect of zinc bacitracin and salinomycin on intestinal microflora and performance of broilers. Poult. Sci. 79, 1311-1319.

Ferket, P.R., 2004. Alternatives to antibiotics in poultry production: Responses, practical experience and recommendations.nutritional biotechnology in the feed and food industries. In: Proc. Alltech's $20^{\text {th }}$ Annual Symp. Eds. Lyons, T.P. \& Jacques, K.A., Nottingham University Press. pp. 57-67.

Gill, C., 2001. Safe and sustainable feed ingredients. Feed Int. 22 (3), 40-45.

Hadorn, R., Wiedmer, H. \& Feuerstein, D., 2000. Effect of different dosages of an organic-acid mixture in broiler diets. Archive Geflügelkunde 65 (1), 22-27.

Henry, P.R., Ammerman, C.B. \& Miles, R.D., 1986. Influence of virginiamycin and dietary manganese on performance, manganese utilization, and intestinal tract weight of broilers. Poult. Sci. 65, 321-324.

Hertrampf, J.W., 2001. Alternative antibacterial performance promoters. Poult. Int. 40, 50-52.

Hill, C.H., Keeling, A.D. \& Kelly, J.W., 1957. Studies on the effects of antibiotics on the intestinal weights of chicks. J. Nutr. 62, 255-267.

Hofacre, C.L., Beacorn, T., Collet, S. \& Mathis, G., 2003. Using competitive exclusion, mannanoligosaccharide and other intestinal products to control necrotic enteritis. J. Appl. Poult. Res. 12, 60-64.

Hooge, D.M., 2004. Meta-analysis of broiler chicken pen trials evaluating dietary mannan oligosaccharide, 1993-2003. Int. J. Poult. Sci. 3 (3), 163-174.

Hooge, D.M., Sims, M.D., Sefton, A.E., Connoly, A. \& Spring, P.S., 2003. Effect of dietary mannan oligosaccharide, with or without bacitracin or virginiamycin on live performance of broiler chickens at relatively high stocking density on new litter. J. App. Poult. Res. 12, 461-467.

Iji, P.A., Saki, A.A. \& Tivey, D.R., 2001. Intestinal structure and function of broiler chickens on diets supplemented with a mannan oligosaccharide. J. Sci. Food Agri. 81, 1186-1192.

Izat, A.L., Adams, M.H., Cabel, M.C., Colberg, M., Reiber, M.A., Skinner, J.T. \& Waldroup, P.W., 1990a. Effects of formic acid or calcium formate in feed on performance and microbiological characteristics of broilers. Poult. Sci. 69, 1876-1882.

Izat, A.L., Tidwell, N.M., Thomas, R.A., Reiber, M.A., Adams, M.H., Colberg, M. \& Waldroup, P.W., 1990b. Effect of a buffered propionic acid in diets on the performance of broiler chickens and on microflora of the intestine carcass. Poult. Sci. 69, 818-826.

Jin, L.Z., Ho, Y.W., Abdullah, N., Ali, M.A. \& Jalaludin, S., 1998. Effects of adherent Lactobacillus cultures on growth, weight of organs and intestinal microflora and volatile fatty acids in broilers. Anim. Feed Sci. 70, 197-209.

Jin, L.Z., Ho, Y.W., Abdullah, N. \& Jalaludin, S., 2000. Digestive and bacterial enzyme activities in broilers fed diets supplemented with Lactobacillus cultures. Poult. Sci. 79, 886-891.

Kocher, A., 2005. AGP alternatives- part IV. Poultry production without AGPs- Challenges and solutions. World Poultry 21 (9), 32-33.

Kumprecht, I., Zobac, P., Siske, V., Sefton, A.E. \& Spring, P., 1997. Effect of dietary mannan oligosaccharide level on performance and nutrient utilization of broilers. Poult.Sci. 76 (Suppl. 1), 132.

Linge, P., 2005. The use of probiotics and yeast derivates in India. World Poult. 21 (10), 12-15.

Lückstädt, C., 2005. Acid-phytobiotic blends. A sustainable alternative for feed safety, animal health and natural growth promotion in pig farming. Feed Mix, 13 (4), 25-27.

Mabbett, T., 2005. Acid test for feed grain preservation. Feed Int. 26 (8), 12-17.

McCartney, E., 2001. Feed Hygiene and acidifiers. Feed Int. 22 (2), 20-23.

Mellor, S., 2000. Nutraceuticals-alternatives to antibiotics. World Poultry 16 (2), 30-33.

Molnár, A.K., Podmaniczky, B., Kürti, P., Juhász, Zs., Jensen, M.M., Gerendai, D. \& Szábo, Zs., 2005. Influence of Bacillus subtilis on broiler performance. Proc. European Symp. Poultry Nutrition. September 25-29, 2005, Balatonfüred, Hungary. pp. 273-275.

Naumann, C. \& Bassler, R., 1993. Chemical Analyses of Feedstuff. Method book III. (3rd ed.). VDLUFAPress. Darmstadt, Germany.

NRC, 1994. Nutrient Requirements of Poultry. 9th rev. ed. National Academy Press, Washington, D.C., USA. 
Oyofo, B.A., DeLoach, J.R., Corrier, D.E., Norman, J.D., Ziprin, R.L. \& Molenhauer, H.H., 1989. Prevention of Salmonella typhimurium colonization of broilers with D-mannose. Poult. Sci. 68, 1351-1356.

Panda, A.K., Reddy, M.R. \& Praharaj, N.K., 2001. Dietary supplementation of probiotic on serum cholesterol and gut microflora of broilers. Indian J. Anim. Sci. 71 (5), 488-490.

Patten, J.D. \& Waldroup, P.W., 1988. Use of organic acids in broiler diets. Poult. Sci. 67, 1178-1182.

Plail, R., 2006. The innovative power of probiotics. Poult Int. 45 (6), 34-36.

Ricke, S.C., 2003. Perspective on the use of organic acids and short chain fatty acids as antimicrobials. Poult. Sci. 82, 632-639.

Roy, R.D., Edens, F.W., Parkhurst, C.R., Qureshi, M.A. \& Havenstein, G.B., 2002. Influence of a propionic acid feed additive on performance of turkey poults with experimentally induced poult enteritis and mortality syndrome. Poult. Sci. 81, 951-957.

SAS, 1991. SAS ${ }^{\circledR}$ User's Guide: Statistics. Version 6.03 ed. SAS Institute Inc., Cary, N.C., USA.

Savage, T.F., Zakrzewska, E.I. \& Andreasan, J.R., 1997. The effects of feeding mannan oligosaccharide supplemented diets to poults on performance and the morphology of the small intestine. Poult. Sci.76 (Suppl. 1), 139 (Abstr.).

Sefton, A.E., Sims, M.D. \& Collett, S., 2002. Evaluation of Bio-Mos in commercial broiler chickens. Poult. Sci. 80 (Suppl. 1), 77. (Abstr.).

Şenköylü, N., Şamli, H.E., Akyürek, H. \& Agma, A., 2005. Impacts of organic acids and nutrient density of basal diets on broiler growth and gut histomorphology. Proc. $15^{\text {th }}$ European Symp. Poultry Nutrition. September 25-29, 2005, Balatonfüred, Hungary. pp. 398-400.

Shafey, T.M., Al-Mufarej, S., Shalaby, M.I. \& Jarlenabi, A.J., 2001. The effect of feeding mannanoligosaccharides (Bio-Mos) on the performance of meat chickens under two different vaccination programs. Asian-Aust. J. Anim. Sci., 14, 559-563.

Shane, M.S., 2001. Mannan oligosaccharides in poultry nutrition: mechanism and benefits. In: Proc. Alltech's $17^{\text {th }}$ Annual Symp., Science \& Technology in the Feed Industry. Eds Lyons, T.P. \& Jacques, K.A., Nottingham University Press. pp. 65-77.

Sims, M.D. \& Sefton, A.E., 1999. Comparative effects of mannan oligosaccharide and an antibiotic growth promoter on performance of commercial broilers. Poster presented at the $50^{\text {th }}$ North Central Avian Disease Conference, Vancouver, British Columbia, Canada.

Skinner, J.T., Izat, A.L. \& Waldroup, P.W., 1991. Research Note: Fumaric acid enhances performance of broiler chickens. Poult. Sci. 70, 1444-1447.

Spring, P., 1999. Modes of action of dietary mannan oligosaccharide as a growth enhancer. Zootech. Int. 22, 34-36.

Vanbella, N., Teller, E. \& Focant, M., 1990. Probiotics in animal nutrition: a review. Arch. Anim. Nutr. 40, 543-567.

Visek, W.J., 1978. The mode of growth promotion by antibiotics. J. Anim. Sci. 46, 1447-1469.

Waldroup, P.W., Edgar, O., Oviedo-Rondon \& Fritts, C.A., 2003a. Comparison of Bio-Mos ${ }^{\circledR}$ and antibiotic feeding program in broiler diets containing copper sulphate. Int. J. Poult. Sci., 2 (1), 28-31.

Waldroup, P.W., Fritts, C.A. \& Fenglan Yan, 2003b. Utilization of Bio-Mos ${ }^{\circledR}$ Mannan oligosaccharide and Bioplex ${ }^{\circledR}$ copper in broiler diets. Int. J. Poult. Sci. 2 (1), 44-52.

Wenk, C., 2000. Recent advances in animal feed additives such as metabolic modifiers, antimicrobial agents, probiotics, enzymes and highly available minerals. Review. Asian-Aust. J. Anim. Sci. 13: 86-95.

Yeo, J. \& Kyu-1 Kim, 1997. Effect of feeding diets containing an antibiotic, a probiotic, yucca extract on growth and intestinal urease activity in broiler chicks. Poult. Sci. 76, 381-385.

Zhang, K.Y., Yan, F., Keen, C.A. \& Waldroup, P.W., 2005. Evaluation of microencapsulated essential oils and organic acids in diets for broiler chickens. Int. J. Poult. Sci. 4 (9), 612-619. 